\title{
Effect of Age and Occupation on Customer Delight: An Empirical Study With Respect To Departmental Store
}

\author{
N. Kasambu ${ }^{1}$ and R. Sritharan ${ }^{2}$ \\ ${ }^{1}$ Research Scholar, ${ }^{2}$ Assistant Professor \\ ${ }^{1 \& 2}$ Department of Business Administration, Annamalai University, Tamil Nadu, India \\ E-Mail: nkasambu@gmail.com, srisrithar13@gmail.com
}

\begin{abstract}
Delighting customer means exceeding the expectations of the customer. Since departmental stores provides homogenous products and services to its customers there must unique attributes that not exactly meet but also surpass the customer's needs and expectation and gratify them. Customer delight is one of the major factors that play a significant role in deciding on whether to do a business with a certain bank or not. Customer delight is giving customers the direct experience. The main aim of the article is to measure the Customer Delight in Departmental Stores.
\end{abstract}

Keywords: Customer Delight, Departmental Stores, Factors, Expectations

\section{INTRODUCTION}

Delight is the ultimate objectives of a company's achievement, so that there are some efforts made to establish the delight. One of which is by improving the justice, esteem and finishing touch. There are has a very important role because it distinguishes a company or services with the others.

Schiffman and Kanuk, (2004) has been defined as "the individual's perception of the performance of the product or service in relation to his or her expectations". Ekini et al., (2008) have been identified a highly individualized process based on the customers' demands and needs Patterson, (1997) explained the experience goes away satisfaction, with pleasurable, Experience is involved, and fulfilling expectations for the customer, that's called customer delight.

Kumar et al., (2001) said that an emotion composed of joy, exhilaration, thrill, or exuberance are defies as customer delight. This emotional reaction leads to word of mouth. Customer delight has become an important area of study with the realization that satisfaction alone does not necessarily ensure key customer behavior such as loyalty.

A departmental store may be described as a large retail organization having number of departments in the same building under centralized control. Each department deals in particular type of trade and is a complete unit in it.A departmental store is a large retail trading organization. It has several departments, which are classified and organized respectively. Departments are made as per different types of goods to be sold. For example, individual departments are established for selling packed food goods, groceries, garments, stationery, cutlery, cosmetics, medicines, computes, sports, furniture, etc., So that consumers can purchase all basic household requirements under one roof. It provides them maximum shopping convenience and therefore, called as 'one spot shopping'.

The departmental stores originated in the European countries during the 19th century. The first departmental store known as BON MARCHE was established in France in the year 1852. Two more departmental stores viz; the LOUVRE and the PRINTEMPS were established in 1855 and 1856 respectively.

Gradually the departmental stores started getting immense popularity. In England, departmental stores came into existence in 1840 and in the U.S.A. in the middle of nineteenth century.

\section{STATEMENT OF PROBLEM}

Customers are the most important for all departmental stores. The existing customers retain their challenge; it is important for customers to understand what they want to maintaining and retain customers. New customers are not about the intention of attracting departmental stores are important for profit success, maintaining customers loyalty is a key factor in deciding whether a business can do the customer's happiness. Customers are happy with the new experience and bring happiness back to customers. Customers will be loyal if they are happy. Efforts have been made to measure the customer happiness of to-day's fastpaced and competitive world.

\section{REVIEW OF LITERATURE}

Evans and Burns (2007) identified findings from research methods used to study customer delight during product evaluation. The results are framed in terms of existing models, highlighting in adequacies in the assumptions these models make.

Adam Finn (2014) explained the value of merely satisfying customers and instead focused attention on the importance of customer delight. Then it takes advantage of a larger sample and additional measures to address construct 
measurement issues and to determine whether customer delight is something more than a nonlinear effect of satisfaction on intention.

Gokul Kumar et al., (2018) investigated relationship between the customer delight variables and overall satisfaction of the departmental stores and also the factor influencing the customer satisfaction. Customer delight is one of the major factors that play a significant role in deciding whether to do a business with the certain departmental stores or not. Hence an attempt has been made to measure the customer delight of departmental stores.

Saquib Raheem (2011) initiated with exploratory inquiry through personal interviews to identify the elements that create delight in the mind of customers. Departmental stores can be delighted not just by their but by reaching beyond the expectations. The findings revealed that all variables are very necessary in delighting the customers.

\section{OBJECTIVE OF THE STUDY}

1. To identified the major factors influencing the customer delight in departmental stores.

2. To explore the relationship between Demographic characteristics and customer delight.

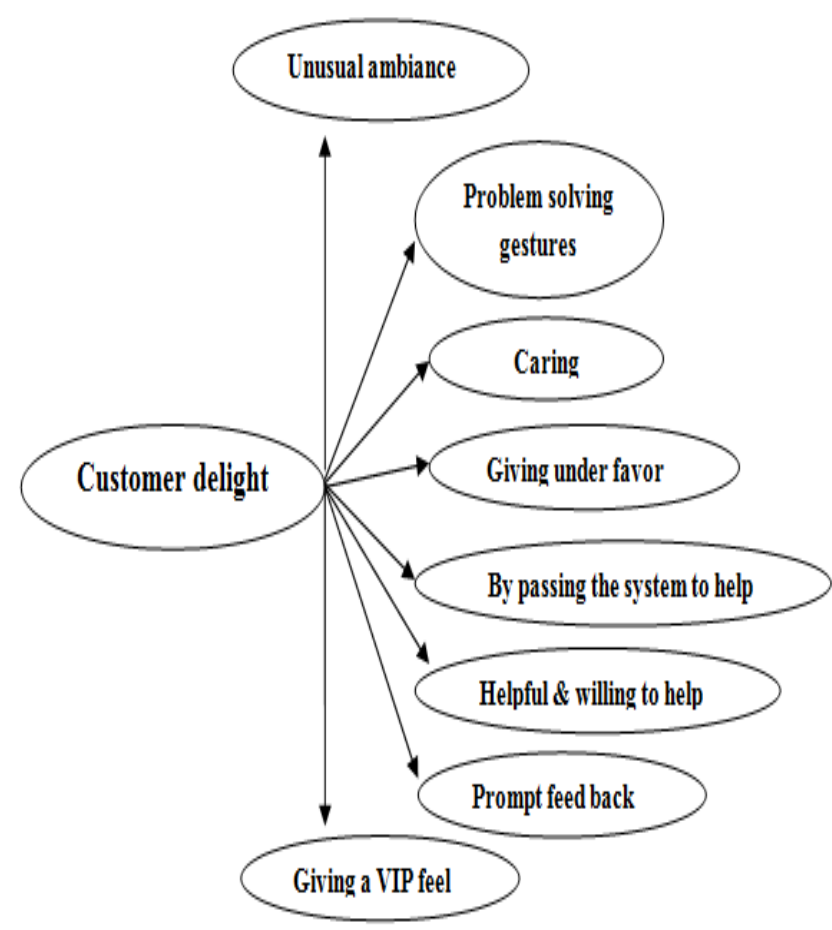

Fig. 1 Factors influencing consumer delight

\section{METHODOLOGY}

It consists of 50 respondents. Both primary and secondary data were used in the study questionnaire. Primary data are collected from the respondents through questionnaire method. Secondary data are collected from books, magazines, journals and internet. One way ANOVA, Chisquare test and t-test have been used for analysis.

TABLe I Continue PuRchase In With The DePartmental STORES IN FUTURE

\begin{tabular}{|l|c|c|}
\hline Opinion & $\begin{array}{c}\text { No. of } \\
\text { Respondents }(\mathbf{n = 5 0})\end{array}$ & $\begin{array}{c}\text { Percentage } \\
(\mathbf{1 0 0 \%})\end{array}$ \\
\hline Yes & 35 & 70 \\
\hline No & 15 & 30 \\
\hline Total & 50 & 100 \\
\hline
\end{tabular}

With the above table I show that $70 \%$ of the respondents will continue their purchase with the departmental stores in future and $30 \%$ of the respondents are not willing to continue their purchase with the departmental stores in the future.

TABLE II FACTORS INFLUENCING CUSTOMER DELIGHT

\begin{tabular}{|l|c|c|c|c|}
\hline \multicolumn{1}{|c|}{ Opinion } & Low & High & S.D & Mean \\
\hline Unusual ambiance & 16 & 34 & 3.553 & 15.22 \\
\hline Problem solving gestures & 28 & 22 & 10497 & 8.38 \\
\hline Caring & 24 & 26 & 2.061 & 12.28 \\
\hline Giving under favor & 29 & 21 & 2.035 & 12.32 \\
\hline By passing the system to help & 27 & 26 & 2.086 & 6.66 \\
\hline Helpful \& willing to help & 16 & 34 & 1.557 & 7.84 \\
\hline Prompt feed back & 22 & 28 & 2.144 & 12.12 \\
\hline Giving a VIP feel & 22 & 28 & 3.559 & 16.50 \\
\hline Overall Customer delight & 17 & 33 & 14.543 & 91.32 \\
\hline
\end{tabular}

Above table II indicates that the most important factor influencing customer delight is "giving a VIP feel" (mean=16.50) followed by "unusual ambiance" (mean = 15.22), and "giving undue favor" (mean=12.32). The least important factor influencing customer delight is "by passing the system to help" (mean=6.66).

From the table III reveals that there is no significant association between age of the respondents and their overall customer delights. Hence, the calculated value greater than table value $(\mathrm{p}>0.05)$.

Table also explains that the factor unusual ambiance is high for the age group of between 31-40 years (86.7\%) and overall customer delight is high for the same age group $(86.7 \%)$. 'Problem solving' gestures is low for the respondents below 20 years (75\%). 'Caring' is low the respondents above 40 years.' Giving undue favor' is low for the respondents above 40 years $(8.3 \%)$.

'By passing the system' is high for the respondents above 40 years $(83.3 \%)$. 'Helpful and willing' to help is high for the respondents below 20 years (100\%). 'Prompt feedback' is low for the respondents above 40 years $(83.3 \%)$. Giving a VIP feel' is low for the respondents below 20 years (75\%). 
Table II Association Between Age And Overall Customer Delights

\begin{tabular}{|c|c|c|c|c|c|c|}
\hline \multirow{2}{*}{$\begin{array}{l}\text { Various dimensions } \\
\text { customer delights }\end{array}$} & \multirow{2}{*}{$\begin{array}{c}\text { Age } \\
\mathrm{Z} 0 \mathrm{yrs} \\
(\mathrm{n}=4)\end{array}$} & \multicolumn{5}{|c|}{ Statistical inference } \\
\hline & & $\begin{array}{c}21 \text { to } 30 \text { yrs } \\
(\mathrm{n}=25)\end{array}$ & $\begin{array}{c}31 \text { to } 40 \text { yrs } \\
(n=15)\end{array}$ & $\begin{array}{c}\text { Above } 40 \text { yrs } \\
(n=6)\end{array}$ & $\begin{array}{c}\text { Total } \\
(\mathrm{n}=50)\end{array}$ & \\
\hline \multicolumn{7}{|c|}{ Unusual ambiance } \\
\hline Low & 5 & 8 & 3 & 2 & 18 & $\begin{array}{c}\mathrm{X} 2=4.890 \mathrm{Df}=3 \\
.180>0.05 \\
\text { Not Significant }\end{array}$ \\
\hline High & 3 & 12 & 15 & 2 & 32 & \\
\hline \multicolumn{7}{|c|}{ Problem solving gestures } \\
\hline Low & 5 & 13 & 7 & 2 & 27 & $\begin{array}{c}\mathrm{X} 2=2.322 \mathrm{Df}=3 \\
.508>0.05 \text { Not } \\
\text { Significant }\end{array}$ \\
\hline High & 2 & 9 & 8 & 4 & 23 & \\
\hline \multicolumn{7}{|c|}{ Caring } \\
\hline Low & 4 & 16 & 4 & 4 & 28 & $\begin{array}{c}\mathrm{X} 2=5.695 \mathrm{Df}=3 \\
.127>0.05 \mathrm{Not} \\
\text { Significant }\end{array}$ \\
\hline High & 2 & 9 & 9 & 2 & 22 & \\
\hline \multicolumn{7}{|c|}{ Giving undue favor } \\
\hline Low & 2 & 14 & 5 & 6 & 27 & $\begin{array}{c}\mathrm{X} 2=4.012 \mathrm{Df}=3 \\
.260>0.05 \text { Not } \\
\text { Significant }\end{array}$ \\
\hline High & 3 & 10 & 8 & 2 & 23 & \\
\hline \multicolumn{7}{|c|}{ Bypassing the system to help } \\
\hline Low & 2 & 13 & 6 & 3 & 24 & $\begin{array}{c}\mathrm{X} 2=4.020 \mathrm{Df}=3 \\
.259>0.05 \text { Not } \\
\text { Significant }\end{array}$ \\
\hline High & 4 & 10 & 8 & 4 & 26 & \\
\hline \multicolumn{7}{|c|}{ Helpful \& willing to help } \\
\hline Low & 1 & 8 & 2 & 2 & 13 & $\begin{array}{c}\mathrm{X} 2=7.415 \mathrm{Df}=3 \\
.060>0.05 \text { Not } \\
\text { Significant }\end{array}$ \\
\hline High & 5 & 15 & 13 & 4 & 37 & \\
\hline \multicolumn{7}{|c|}{ Prompt feedback } \\
\hline Low & 4 & 12 & 7 & 4 & 27 & $\begin{array}{c}\mathrm{X} 2=4.012 \mathrm{Df}=3 \\
.260>0.05 \mathrm{Not} \\
\text { Significant }\end{array}$ \\
\hline High & 2 & 10 & 8 & 3 & 23 & \\
\hline \multicolumn{7}{|c|}{ Giving a VIP feel } \\
\hline Low & 4 & 12 & 5 & 3 & 24 & $\begin{array}{c}\mathrm{X} 2=4.901 \mathrm{Df}=3 \\
.179>0.05 \mathrm{Not} \\
\text { Significant }\end{array}$ \\
\hline High & 2 & 11 & 10 & 3 & 26 & \\
\hline \multicolumn{7}{|c|}{ Overall customer delights } \\
\hline Low & 3 & 11 & 3 & 2 & 19 & $\begin{array}{c}\mathrm{X} 2=5.546 \mathrm{Df}=3 \\
.136>0.05 \text { Not } \\
\text { Significant }\end{array}$ \\
\hline High & 3 & 12 & 14 & 2 & & \\
\hline
\end{tabular}

Table IV reveals that there is no significant difference between occupation of the respondents and their overall customer delights. Hence, the calculated value greater than table value $(\mathrm{p}>0.05)$. Table also shows that the factors 'Unusual ambiance' (Mean $=15.95)$, 'Problem solving gestures $($ Mean 8.68), 'Caring' $($ Mean $=12.84)$, 'Giving undue favor' (Mean = 12.68), Bypassing the system to help $($ Mean $=7.32)$, 'Helpful and willing to help $($ Mean $=8.26)$, 'Prompt Feedback' $($ Mean = 17.00), 'Giving a VIP feel' $($ Mean $=95.16 .50)$.

But 'Prompt feedback' (Mean $=12.50$ ) is given to respondents doing business. 
TABle Iv One Way ANova BetweEn OcCuPation ANd Overall Customer Delight

\begin{tabular}{|c|c|c|c|c|c|c|}
\hline Occupation & Mean & S.D & SS & Df & MS & Statistical inference \\
\hline \multicolumn{7}{|c|}{ Unusual ambiance } \\
\hline Between Groups & & & 31.515 & 3 & 10.505 & $\begin{array}{c}\mathrm{F}=.82 \\
3.488>0.05 \text { Not Significant }\end{array}$ \\
\hline Students $(n=7)$ & 15.41 & 3.890 & & & & \\
\hline House wife $(n=4)$ & 14.00 & 2.708 & & & & \\
\hline Employed $(n=19)$ & 15.95 & 3.135 & & & & \\
\hline Business $(n=10)$ & 14.00 & 4.028 & & & & \\
\hline Within Groups & & & 587.065 & 46 & 12.762 & \\
\hline \multicolumn{7}{|c|}{ Problem solving gestures } \\
\hline Between Groups & & & 8.957 & 3 & 2.986 & $\mathrm{~F}=1.362$ \\
\hline Students $(n=7)$ & 8.59 & 1.502 & & & & \\
\hline House wife $(n=4)$ & 7.80 & 2.517 & & & & \\
\hline Employed $(\mathrm{n}=19)$ & 8.68 & 1.250 & & & & \\
\hline Business $(n=10)$ & 7.80 & 1.398 & & & & \\
\hline Within Groups & & & 100.823 & 46 & 2.192 & \\
\hline \multicolumn{7}{|c|}{ Caring } \\
\hline Between Groups & & & 15.389 & 3 & 5.130 & $\begin{array}{c}\mathrm{F}=1.225 \\
.312>0.05 \text { Not Significant }\end{array}$ \\
\hline Students $(\mathrm{n}=7)$ & 11.88 & 1.996 & & & & \\
\hline House wife $(n=4)$ & 11.00 & 2.582 & & & & \\
\hline Employed $(n=19)$ & 12.84 & 2.007 & & & & \\
\hline Business $(n=10)$ & 12.40 & 2.011 & & & & \\
\hline Within Groups & & & 192.691 & 46 & 4.186 & \\
\hline \multicolumn{7}{|c|}{ Giving undue favour } \\
\hline Between Groups & & & 9.625 & 3 & 3.208 & $\begin{array}{c}\mathrm{F}=.764 \\
.520>0.05 \text { Not Significant }\end{array}$ \\
\hline Students $(\mathrm{n}=7)$ & 12.00 & 2.622 & & & & \\
\hline House wife $(n=4)$ & 11.25 & 2.500 & & & & \\
\hline Employed $(n=19)$ & 12.68 & 1.734 & & & & \\
\hline Business $(n=10)$ & 12.60 & 1.075 & & & & \\
\hline Within Groups & & & 193.255 & 46 & 4.201 & \\
\hline \multicolumn{7}{|c|}{ Bypassing the system to help } \\
\hline Between Groups & & & 24.406 & 3 & 8.135 & $\begin{array}{c}\mathrm{F}=1.982 \\
.130>0.05 \text { Not Significant }\end{array}$ \\
\hline Students $(\mathrm{n}=7)$ & 5.76 & 2.107 & & & & \\
\hline House wife $(n=4)$ & 6.25 & 2.062 & & & & \\
\hline Employed $(\mathrm{n}=19)$ & 7.32 & 2.056 & & & & \\
\hline Business $(n=10)$ & 7.10 & 1.792 & & & & \\
\hline Within Groups & & & 188.814 & 46 & 4.105 & \\
\hline \multicolumn{7}{|c|}{ Helpful \& willing to help } \\
\hline Between Groups & & & 7.503 & 3 & 2.501 & $\begin{array}{c}\mathrm{F}=1.034 \\
.386>0.05 \text { Not Significant }\end{array}$ \\
\hline Students $(n=7)$ & 7.35 & 1.766 & & & & \\
\hline House wife $(n=4)$ & 7.75 & 1.258 & & & & \\
\hline Employed $(n=19)$ & 8.26 & 1.327 & & & & \\
\hline Business $(n=10)$ & 7.90 & 1.663 & & & & \\
\hline Within Groups & & & 111.217 & 46 & 2.418 & \\
\hline \multicolumn{7}{|c|}{ Prompt feedback } \\
\hline Between Groups & & & 9.163 & 3 & 3.054 & $\begin{array}{c}\mathrm{F}=.650 \\
.587>0.05 \text { Not Significant }\end{array}$ \\
\hline Students $(\mathrm{n}=7)$ & 11.53 & 2.961 & & & & \\
\hline House wife $(n=4)$ & 12.25 & 2.062 & & & & \\
\hline
\end{tabular}




\begin{tabular}{|c|c|c|c|c|c|c|}
\hline Employed $(\mathrm{n}=19)$ & 12.42 & 1.742 & & & & \\
\hline Business $(n=10)$ & 12.50 & .972 & & & & \\
\hline Within Groups & & & 216.117 & 46 & 4.698 & \\
\hline \multicolumn{7}{|c|}{ Giving a VIP feel } \\
\hline Between Groups & & & 18.659 & 3 & 6.220 & $\begin{array}{c}\mathrm{F}=.475 \\
.701>0.05 \text { Not Significant }\end{array}$ \\
\hline Students $(n=7)$ & 16.06 & 4.220 & & & & \\
\hline House wife $(n=4)$ & 15.00 & 5.033 & & & & \\
\hline Employed $(n=19)$ & 17.00 & 2.867 & & & & \\
\hline Business $(n=10)$ & 16.90 & 3.213 & & & & \\
\hline Within Groups & & & 601.841 & 46 & 13.084 & \\
\hline \multicolumn{7}{|c|}{ Overall customer delights } \\
\hline Between Groups & & & 566.636 & 3 & 188.879 & $\begin{array}{c}\mathrm{F}=.887 \\
.455>0.05 \text { Not Significant }\end{array}$ \\
\hline Students $(n=7)$ & 88.59 & 16.356 & & & & \\
\hline House wife $(n=4)$ & 85.00 & 19.305 & & & & \\
\hline Employed $(n=19)$ & 95.16 & 13.368 & & & & \\
\hline Business $(n=10)$ & 91.20 & 11.458 & & & & \\
\hline Within Groups & & & 9796.244 & 46 & 212.962 & \\
\hline
\end{tabular}

TABle V Association Between Dimensions Of Customer Delight ANd Overall Customer Delight

\begin{tabular}{|c|c|c|c|c|}
\hline \multirow{3}{*}{$\begin{array}{c}\text { Various } \\
\text { dimensions } \\
\text { of customer } \\
\text { delights } \\
\end{array}$} & \multicolumn{3}{|c|}{ Overall customer delights } & \multirow[t]{2}{*}{ Statistical inference } \\
\hline & Low & High & Total & \\
\hline & $(n=18)$ & $(\mathbf{n}=32)$ & $(\mathbf{n}=\mathbf{5 0})$ & \\
\hline \multicolumn{5}{|c|}{ Unusual ambiance } \\
\hline Low & 17 & 0 & 17 & \multirow{2}{*}{$\begin{array}{c}X^{2}=45.888 \\
D f=1.000<0.05 \text { Significant }\end{array}$} \\
\hline High & 1 & 32 & 33 & \\
\hline \multicolumn{5}{|c|}{ Problem solving gestures } \\
\hline Low & 18 & 9 & 27 & \multirow{2}{*}{$\begin{array}{c}\mathrm{X}^{2}=26.105 \\
\mathrm{Df}=1.000<0.05 \text { Significant }\end{array}$} \\
\hline High & 0 & 23 & 23 & \\
\hline \multicolumn{5}{|c|}{ Caring } \\
\hline Low & 16 & 12 & 28 & \multirow{2}{*}{$\begin{array}{c}\mathrm{X}^{2}=24.078 \\
\mathrm{Df}=1.000<0.05 \text { Significant }\end{array}$} \\
\hline High & 2 & 20 & 22 & \\
\hline \multicolumn{5}{|c|}{ Giving undue favor } \\
\hline Low & 17 & 10 & 27 & \multirow{2}{*}{$\begin{aligned} \mathrm{X}^{2} & =26.105 \\
\mathrm{Df}=1.000 & <0.05 \text { Significan }\end{aligned}$} \\
\hline High & 1 & 22 & 23 & \\
\hline \multicolumn{5}{|c|}{ Bypassing the system to help } \\
\hline Low & 11 & 13 & 24 & \multirow{2}{*}{$\begin{array}{c}\mathrm{X}^{2}=.263 \\
\mathrm{Df}=1.608>0.05 \mathrm{Not} \\
\text { Significant }\end{array}$} \\
\hline High & 7 & 19 & 26 & \\
\hline \multicolumn{5}{|c|}{ Helpful \& willing to help } \\
\hline Low & 9 & 4 & 13 & \multirow{2}{*}{$\begin{array}{c}\mathrm{X}^{2}=11.297 \\
\mathrm{Df}=1.001<0.05 \text { Significant }\end{array}$} \\
\hline High & 9 & 28 & 37 & \\
\hline \multicolumn{5}{|c|}{ Prompt feedback } \\
\hline Low & 17 & 10 & 27 & \multirow{2}{*}{$\begin{array}{c}\mathrm{X}^{2}=26.105 \\
\mathrm{Df}=1.000<0.05 \text { Significant }\end{array}$} \\
\hline High & 1 & 22 & 23 & \\
\hline \multicolumn{5}{|c|}{ Giving a VIP feel } \\
\hline Low & 16 & 8 & 24 & \multirow{2}{*}{$\begin{array}{c}X^{2}=33.199 \\
D f=1.000<0.05 \text { Significan }\end{array}$} \\
\hline High & 2 & 24 & 26 & \\
\hline
\end{tabular}


The table $\mathrm{V}$ reveals that there is no significant association between bypassing the system to help of the respondents and their overall customer delights, as the calculated value is greater than table value $(\mathrm{p}>0.05)$. The table also reveals that there is a significant association between unusual ambiance, problem solving gestures, caring, giving undue favor, helpful \& willing to help, prompt feedback and giving a VIP feel of the respondents and their overall customer delights, because the calculated value is less than table value $(\mathrm{p}<0.05)$.

\section{SUGGESTION}

To take care of customers from customers should improve the principles and practices to solve the bulk of the problems. In to-day'sworld, the people who are illiterate people are looking forward to becoming the shopper's customers. The main task of the departmental store is to help the customer get the help of the customer. Positive impact should be for customer problems. So the skill of the members of the departmental store should be reassuring customers and bringing them back again and again.

\section{CONCLUSION}

It was concluded that the services of departmental stores of the most important factor influencing customer delight is "giving a VIP feel" (mean=16.50) followed by "unusual ambiance" (mean = 15.22), "giving undue favour" $($ mean=12.32) and the least important factor influencing customer delight is "by passing the system to help" (mean=6.66). There is a significant association between all the factors contributing to customer delight and overall customer delight except for the factor 'Bypassing the system to help'.

\section{REFERENCES}

[1] Schiffman, L.G. \& Kanuk, L.L. (2004). Consumer Behavior, Pearson Prentice-Hall, Upper Saddle River, NJ.
[2] Howard, John A. \& Jagdish N. Sheth (1969). The Theory of Buyer Behavior. New York: John Wiley.

[3] Adam Finn, A. (2005). Reassessing the foundations of customer delight. Journal of Services Research, 8(2), 103-116.

[4] Anderson, Eugene W. Claes Fornell, \& Donald R. Lehmann (1994, July). Customer Satisfaction, Market Share and Profitability: Findings from Sweden. Journal of Marketing, 58, 53-66.

[5] Arnold, Mark J., Kristy E. Reynolds, Nicole Ponder, \& Jason E. Lueg (2005 August). Customer Delight in a Retail Context: Investigating Delightful and Terrible Shopping Experiences. Journal of Business Research, 58, 1132-45.

[6] Berman, B. (2005). How to delight customers. California Management Review, 48(1), 129-151.

[7] Ekini, Y., Dawes, P. \& Massey, G. (2008). An extended model of the antecedents and consequences of consumer satisfaction for hospitality and services. European Journal of Marketing, 42(1/2), 35-38.

[8] Evans, S. \& A.D. Burns (2007). An investigation of customer delight during product evaluation: Implications for the development of desirable products. Proceedings of the Institution of Mechanical Engineers: Journal of engineering Manufacture, 786, 1625-1640.

[9] Keiningham, T., L. \& Vavra, T., G. (2001). The Customer Delight Principle: Exceeding Customers' Expectations for Bottom-line Success Chicago. American of Marketing Association. 48(1), 29-51.

[10] Kumar, A., Olshavsky, R.W. \& King, M. F. (2001). Exploring the antecedents of customer delight. Journal of Consumer Satisfaction, Dissatisfaction and Complaining Behavior, 14, 14-27.

[11] Kwong, K., K. \& Yau, O., H., M. (2002). The Conceptualization of Customer Delight: Marketing. 42(1/2), 35-38.

[12] Oliver, R., L. \& Rust, R.T. (1997). Customer delight: foundations, findings and managerial insight. Journal of Retailing, 73(3), 311-377.

[13] Patterson, K. (1997). Delighted clients are loyal clients. Rough Notes, 140(3), 221-234.

[14] Rust, Roland T. \& Richard L. Oliver (2000). Should We Delight the Customer? Journal of the Academy of Marketing Science, 28(1), 8694.

[15] Schneider, B. \& Bowen, D. (1999). Understanding customer delight and outrage. Sloan Management Review, 4(1), 35-46.

[16] Szymanski, David M. \& David H. Henard (2001). Customer Satisfaction: A Meta-Analysis of Empirical Evidence. Journal of the Academy of Marketing Science, 29 (winter), 16-35.

[17] Taylor, S., A. \& Baker, T., L. (1994). An assessment of the relationship between service quality and customer satisfaction in the formation of consumers' purchase intentions. Journal of retailing. 70(2), 163-178.

[18] Westbrook, Robert A. (1987 August). Product/Consumption Based Affective Responses and Post purchase Processes. Journal of Marketing Research, 24, 258-70. 